\title{
Hydroclimatic changes in northern Levant over the past 400,000 years
}

\author{
Françoise Gasse ${ }^{\mathrm{a},}$, Laurence Vidal ${ }^{\mathrm{a},}{ }^{*}$, Elise Van Campo ${ }^{\mathrm{b}}$, François Demory ${ }^{\mathrm{a}}$, \\ Anne-Lise Develle ${ }^{\text {c, a }}$, Kazuyo Tachikawa ${ }^{a}$, Ata Elias ${ }^{\mathrm{d}}$, Edouard Bard ${ }^{\mathrm{a}}$, Marta Garcia ${ }^{\mathrm{a}}$, \\ Corinne Sonzogni ${ }^{\text {a }}$, Nicolas Thouveny ${ }^{a}$ \\ ${ }^{a}$ CEREGE, Aix-Marseille Universite, CNRS, IRD, College de France, CEREGE, BP 80, 13545 Aix-en-Provence Cedex 04, France \\ ${ }^{\mathrm{b}}$ ECOLAB, UMR 5245 (CNRS-Universite de Toulouse-INPT), BP 24349, 31062 Toulouse Cedex 9, France \\ ${ }^{c}$ EDYTEM, Univ. de Savoie, UMR 5204, bat. Pole Montagne, 73376 Le Bourget du Lac Cedex, France \\ ${ }^{\mathrm{d}}$ Dept. of Geology, American University of Beirut, Beirut, Lebanon
}

Keywords: Paleoclimatology Lake deposits, Glacial/interglacial cycles Levant

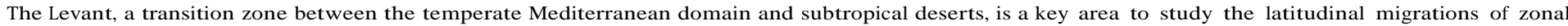

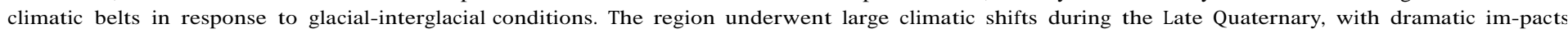

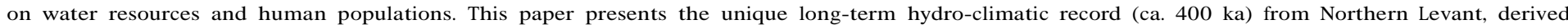

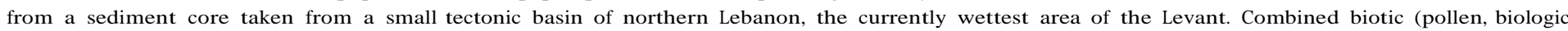

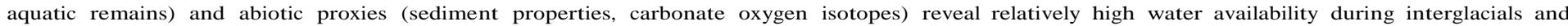

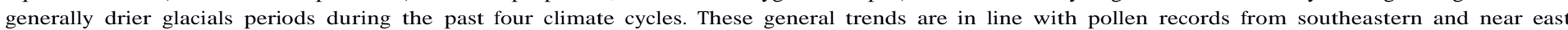

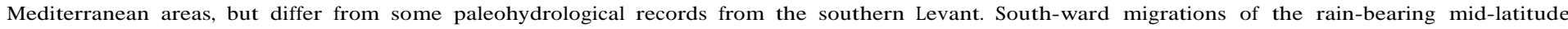

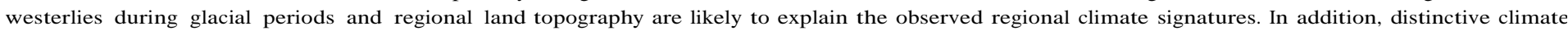

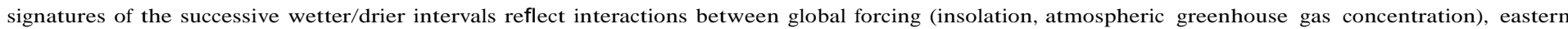

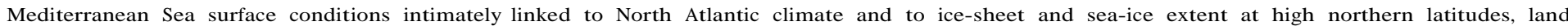

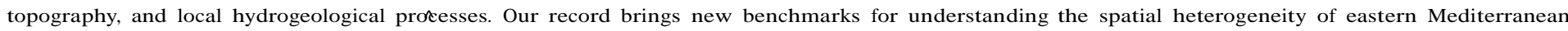
responses to global climate changes.

\section{Introduction}

The Levant (Fig. 1a) underwent in the past large climatic shifts with dramatic impacts on water resources and human populations (Frumkin et al., 2011). The regional climate is intimately tied to the North Atlantic system but also affected by tropical processes, and deeply modulated by steep topography. This results in sharp NorthSouth and West-East hydroclimatic gradients (Enzel et al., 2008). The whole Levant receives most of its moisture during winter from the Eastern Mediterranean Sea (EMS). Cyclones generated in the Mediterranean Sea or penetrating from the North Atlantic are steered by the mid-latitude westerlies and reinforced eastward along the northern Mediterranean coast (Giorgi and Lionello, 2008; Ziv et al., 2010). The strength and position of the "Cyprus cyclones" are key to inland rainfall variability. In summer, high pressure and air subsidence connected with the Indian monsoon system yield heat and drought rising from North to South (Giorgi and Lionello, 2008). In addition the rough orography controls the spatial rainfall distribution. East of narrow coastal plains, mountain ranges running parallel to the sea shore intercept most of the moisture; in their rain-shadow, rainfall decreases drastically eastward. Precipitation exceeds $1800 \mathrm{~mm} / \mathrm{yr}$ above $2000 \mathrm{~m}$ on Mount Lebanon but falls below $50 \mathrm{~mm} / \mathrm{yr}$ along the Dead Sea shore $(425 \mathrm{~m}$ below sea level). Remote forcing factors also modulate the regional climate variability like the North Atlantic Oscillation (Jacobeit et al., 2003) as well as southern origin features like African Sharav cyclones (Alpert and Ziv, 1989) and tropical plumes (Ziv, 2001).

\footnotetext{
* Corresponding author. Tel.: p33 442971596

E-mail address: vidal@cerege.fr (L.Vidal).

1 Deceased.
} 


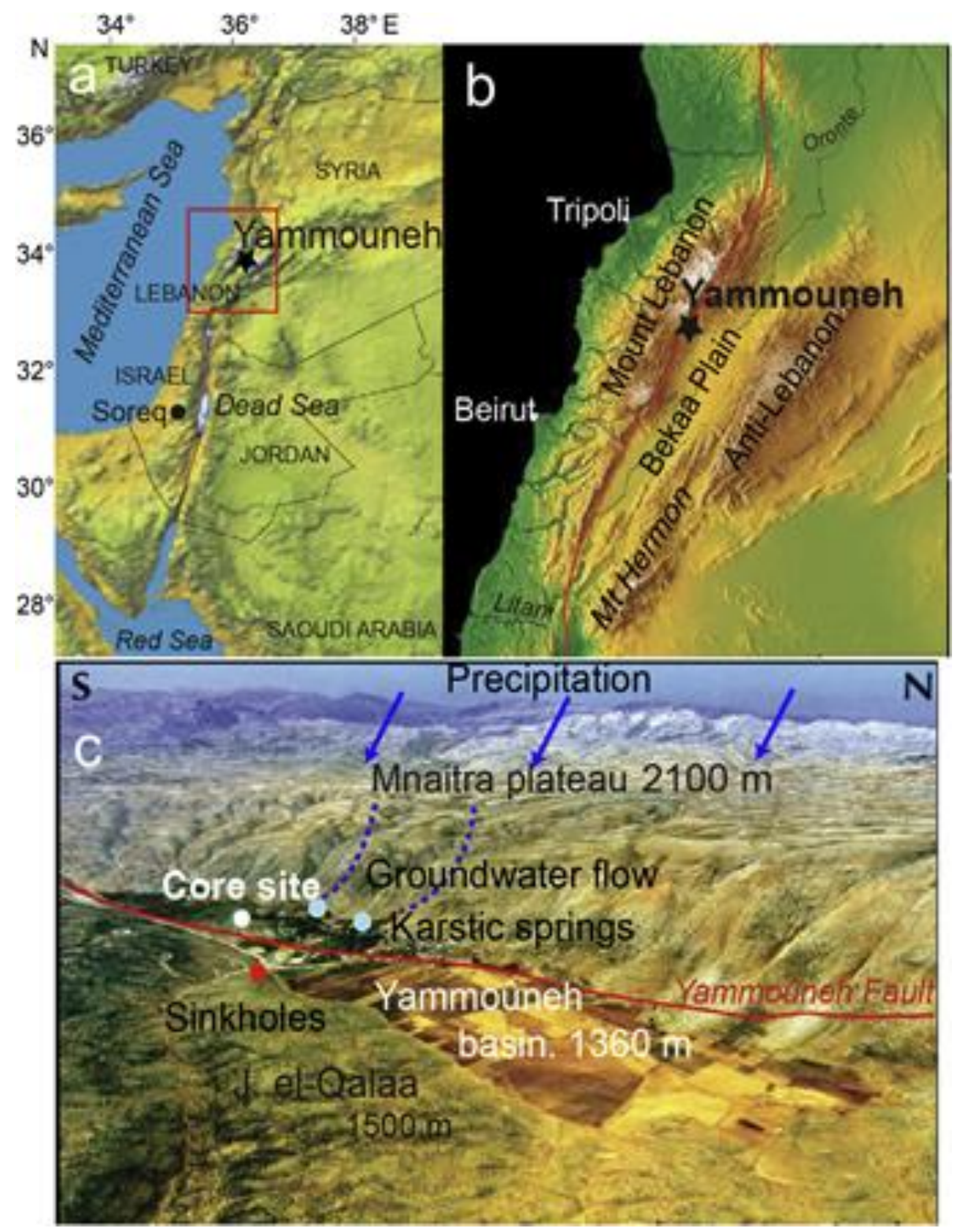

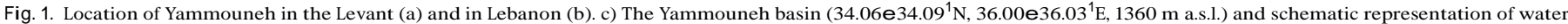
circulation. Red curve: surface trace of the Yammouneh Fault, an active branch of the Levant Fault.

These complex atmospheric and oceanic interactions combined with the specific topography of the region make it very sensitive to climate forcing. Climate change simulations for the 21 st century predict that the eastern Mediterranean area is expected to be one of the most prominent vulnerable areas in response to changing water cycle (Milano et al., 2012). The response of the hydrological cycle in this highly contrasted area on various spatial and temporal scales needs to be further explored to grasp the whole variability range.

The Late Pleistocene climate in the Levant has been the focus of a number of studies based on marine and continental records (Robinson et al., 2006; Enzel et al., 2008; Frumkin et al., 2011). Although all paleohydrological records in the region show pronounced changes over the last climate cycles, there is a marked disparity in spatial coverage between the southern Levant where well dated, long-term records provide detailed information on the glacial-interglacial cycles (Enzel et al., 2008; Lisker et al., 2010; Waldmann et al., 2010), and the northern Levant where few pollen and $d^{18} \mathrm{O}$ records are available (Verheyden et al., 2008; Develle et al., 2010). Although the environmental evolution of the southern part is rather well known, how the whole Levant responded to glacial-interglacial conditions and how global forcing and feedbacks interfered with regional factors, are still unclear Here, our study focuses on a four climate cycles paleolake deposits from northern Lebanon. The upper part of the record was already published in previous studies using multi-proxy approaches (Develle et al., 2010, 2011; Gasse et al., 2011). In this work, the complete hydroclimatic record is presented spanning the last 400 ka using the same approach. First, the combination of the different proxies (sedimentological properties, pollen assemblages and calcite oxygen isotopes derived from ostracods shells) clearly documents the glacial/interglacial variability that is compared with other long-term paleorecords from the eastern Mediterranean area Second, the differences between the successive climate intervals are discussed in the light of global climate signals (atmospheric 
greenhouse gas concentrations and marine benthic foraminiferal stable isotope) in order to depict how regional factors imprint continental climate signatures.

\section{Study area, material and methods}

Our record derives from a lacustrine-palustrine sediment core (71.4 $\mathrm{m}$ long) retrieved from the small tectonic, intra-mountainous Yammouneh basin lying on the eastern flank of Mount Lebanon (Fig. 1b). Hydrologically, the basin depends primarily on precipitation, partly as snow, in the western highlands. From the intensively karstified high Mnaïtra Plateau (Fig. 1c), meltwater swiftly infiltrates and circulates to supply springs emerging along the western edge of the basin. This faulted and fissured basin has been occupied by a freshwater, seasonal or permanent shallow lake, until it was artificially drained in the 1930's.

The core was collected in 2004 after a geoelectric survey, apart from the disturbance of the Yammouneh Fault, using a SEDIDRILL corer. The sediment recovery was of $89 \%$, due to technical problems during coring. The sedimentary sequence shows whitish to pale grey carbonate deposits alternating with thick accumulations of coloured silty clay (Fig. 2a). We combine new data with those already obtained from the upper $36 \mathrm{~m}$ of the core on sedimentological properties, pollen assemblages, and calcite oxygen isotopes $\left(d_{c}\right)$ derived from ostracod shells. Description of the analytical approaches was presented in detail in previous papers (Develle et al.. 2010, 2011; Gasse et al., 2011) and is briefly summarized here.

The major sedimentological features of the sediment core were defined by X-Ray diffractometry (XRD), performed at CEREGE. which allows a semi-quantitative estimate of major mineral phases. In addition, X-Ray Fluorescence (XRF) provided high resolution records of 6 elements $(\mathrm{Ca}, \mathrm{Si}, \mathrm{Fe}, \mathrm{Ti}, \mathrm{K}, \mathrm{Mn})$. XRF analyses were performed using Avaatech (Develle et al., 2011) and Itrax core scanners (at CEREGE) for the upper $36 \mathrm{~m}$ and the core base respectively. XRF results obtained with both instruments were compared using two sections dominated respectively by authigenic carbonates and detrital components and are in good agreement (see supplementary figure S2).

Pollen samples were prepared using the standard palynological procedures (Faegri and Iversen, 1989). Pollen grains were counted at X 400 and X 1000 magnification using an Olympus microscope. Terrestrial pollen frequencies (\%) are based on the pollen sum excluding local hygrophytes and spores of non-vascular cryptogams. Aquatic and marsh pollen percentages are based on the total

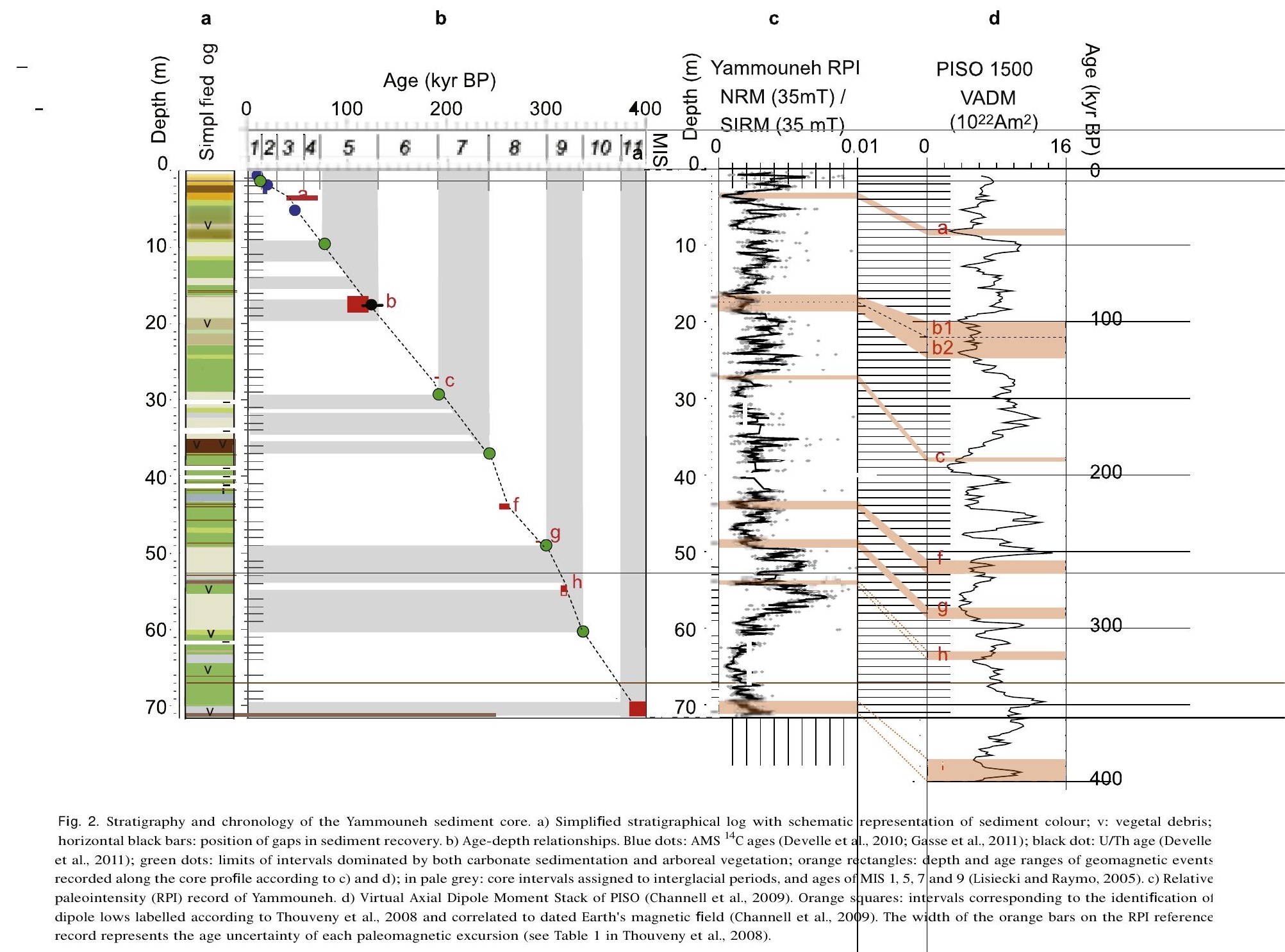


sum of pollen and spores. Arboreal pollen taxa are predominantly represented by Cedrus, Juniperus, Pinus, deciduous Quercus and evergeen Querous; while, non arboreal plant pollen percentages mostly represent steppic plant (Artemisia, Chenopodiaceae, Asteraceae). The modern distribution of the major taxa is given in Gasse et al., 2011. Main pollen taxa and arboreal sum are shown in Figs. 3 and 4 respectively.

The calcite oxygen isotope record $\left(d_{c}\right)$ was derived from the composition of well preserved ostracod valves measured on IRMS coupled to a Kiel Device III at CEREGE. Measurements were normalized to the most widespread taxa (Ilyocypris inermis, present in almost all levels) and corrected for its vital effect estimated in Develle et al., 2010 to obtain values equivalent to that of authigenic calcite precipitated in the same ambient water and applied to the whole sequence. The correction for the source effect using EMS surface $\mathrm{d}^{18} \mathrm{O}$ records as conducted in this study is a crude approach due to chronological uncertainties on both sea and land records (Dd), and the lack of regional temperature reconstruction spanning the past $400 \mathrm{ka}$.

For magnetic properties measurements, a half-core was subsampled using u-channels

$2 \mathrm{~cm})$. Susceptibility was measured at $2 \mathrm{~cm}$ resolution using a Bartington MS2 C loop. Remanent Magnetizations (RM) were measured every $2 \mathrm{~cm}$ with a $2 \mathrm{G}$ superconducting rock magnetometer (DC squids, 2 inches diameter-model 760R Natural). Natural Remanent Magnetization [NRM], Anhysteretic Remanent Magnetization [ARM] imparted

with a $0.05 \mathrm{mT}$ bias field and a $80 \mathrm{mT}$ Alternating Field [AF] and
Isothermal RM [IRM] were acquired at $0.3 \mathrm{~T}$ and $1 \mathrm{~T}$. ARM was selected as the best representative environmental magnetic proxy of magnetic mineral concentration.

Relationships between individual parameters (pollen, sediment and isotope proxies) are illustrated by a Principal Component Analysis ( $\left.\mathrm{PCA}_{\text {Multiproxy}}\right)$. The time series with a mean temporal resolution of $0.9 \mathrm{ka}$ for pollen, isotopes and magnetic properties $0.05 \mathrm{ka}$ for XRF and $2 \mathrm{ka}$ for XRF and colour were resampled every ka (see Supplementary Table 1 and Fig. S1). New sampling and data analysis were conducted using the Analyseries 2.0 software

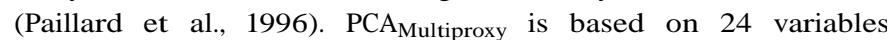
including 385 individuals: (i) colour, coded from the Munsell Soil Color chart at core opening, from 1 to 6 from whitish to dark brown; (ii) content of 5 major minerals (XRD); (iii) XRF relative intensities of 6 elements, (iv) magnetic mineral concentration (ARM), (v) pollen assemblages, (vi) carbonates oxygen isotopes.

\section{Chronology}

The chronology of the Yammouneh sedimentary sequence is based on several dating methodologies. The first upper $36 \mathrm{~m}$ were dated using radiometric ages including 14 calibrated ${ }^{14} \mathrm{C}$ ages of

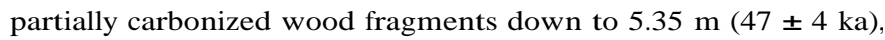
and one U/Th date at $17.70 \mathrm{~m}(124 \pm 10 \mathrm{ka})$ (Develle et al., 2010, 2011). Other U/Th dating attempts on carbonate-dominated levels failed due to the presence of a carbonate detrital fraction of unknown origin (local or eolian). Paleomagnetism was also measured

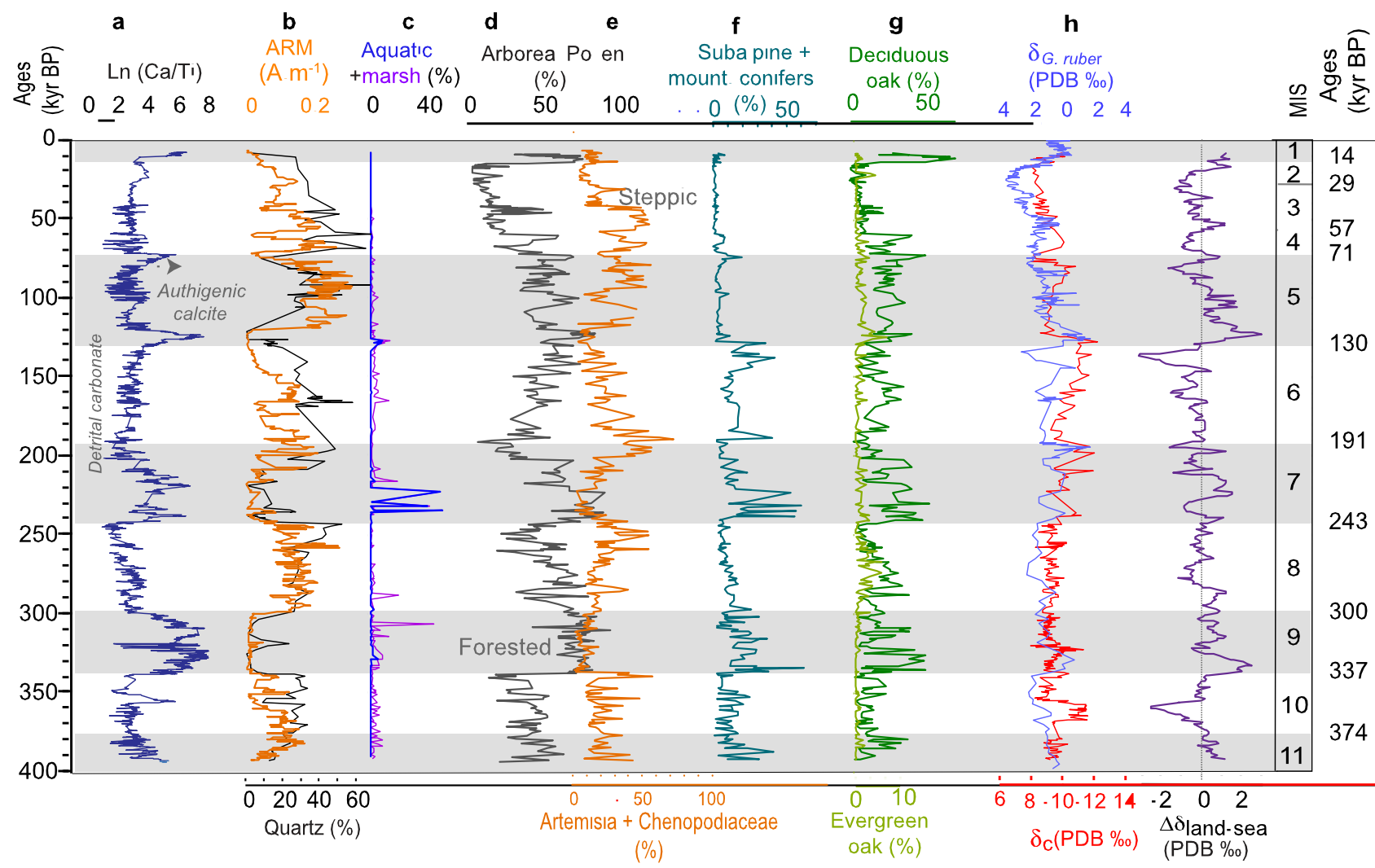

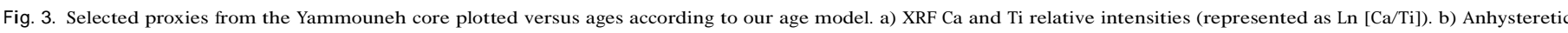

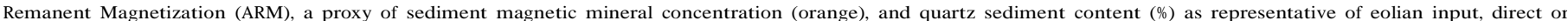

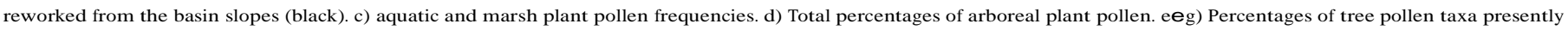

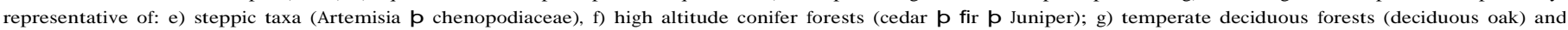

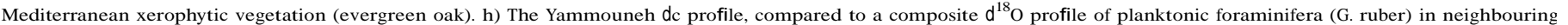

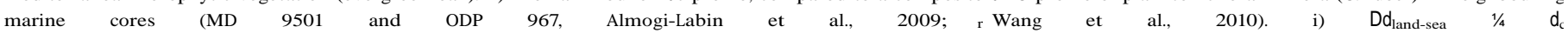

$\mathrm{d}_{\mathrm{G.rube}}$. Right: Marine Isotope Stages (MIS). Pale grey bands: Interglacial periods. 


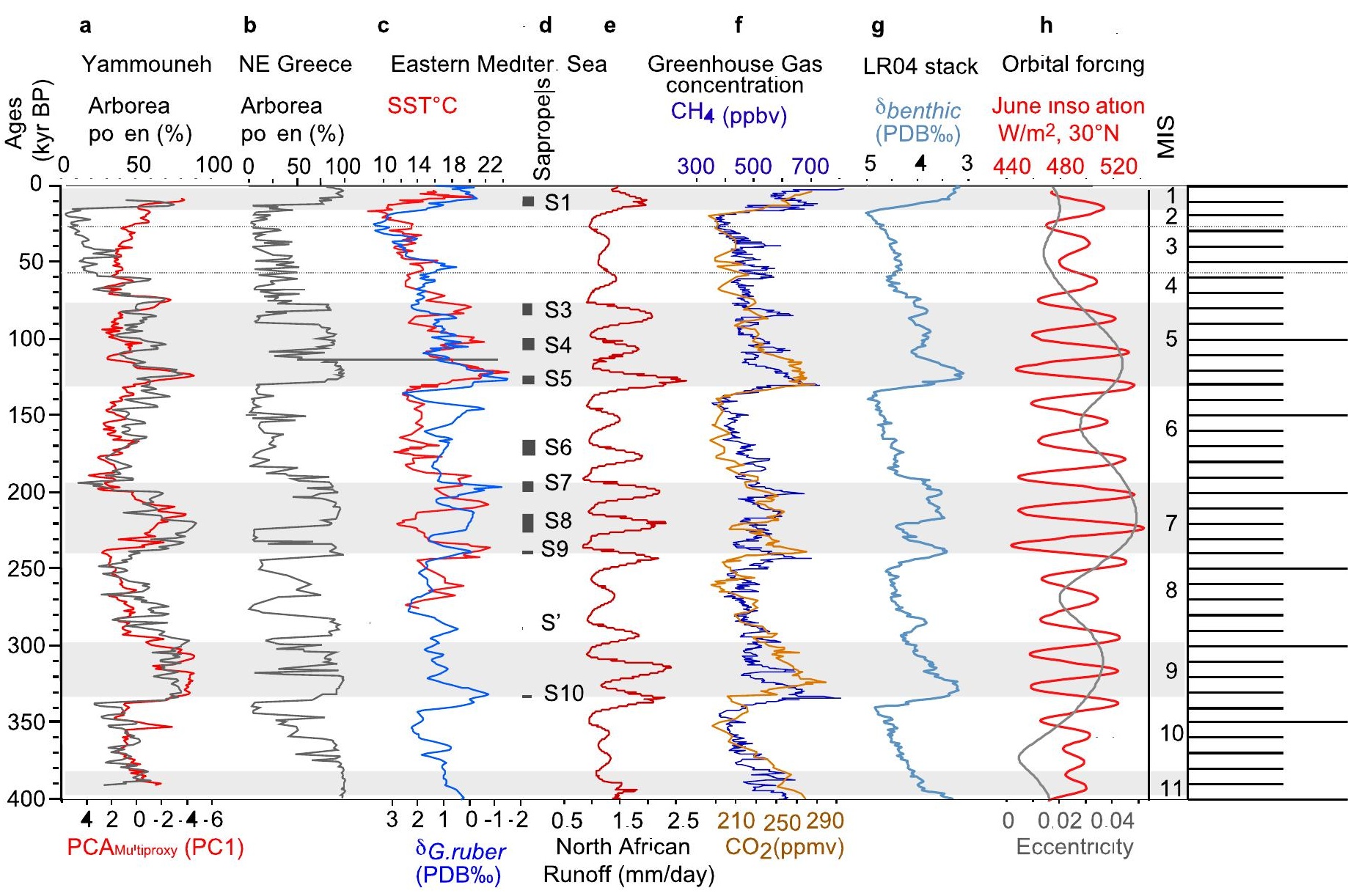

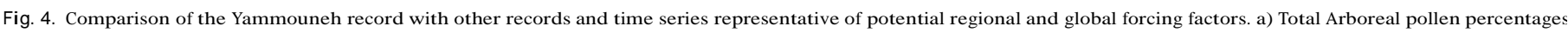

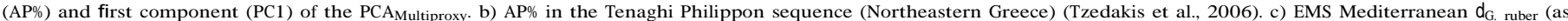

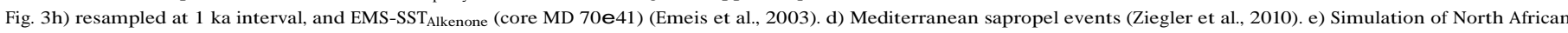

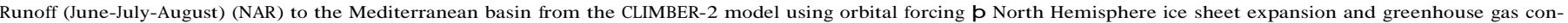

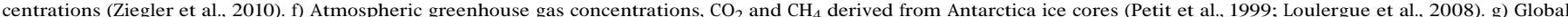

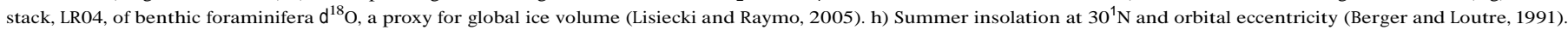

and used to correlate the Yammouneh record to reference records of paleomagnetic excursions (Develle et al., 2011). The obtained age model for the last $240 \mathrm{ka}$ gave a consistent picture of the Yammouneh basin sedimentation assigning carbonated facies to interglacial periods (Develle et al., 2011).

In this study, the chronology of the base of the Yammouneh core (the last $35 \mathrm{~m}$ ) was obtained using the Relative paleointensity (RPI) record. The presented record (for the whole sequence) is based on the normalized ratio Natural Remanent Magnetization over Saturation Isothermal Remanent Magnetization both after an alternating field demagnetization of $35 \mathrm{mT}$ (NRM35mT/SIRM35 mT). Local RPI lows and highs were compared and correlated with geomagnetic dipole moment stacks: RPI and Cosmogenic Beryllium of the Portuguese margin (not showed) and global PISO stack (Fig. 2ced) (Thouveny et al., 2008; Channell et al., 2009). Dipole lows are generally related to known and dated excursions. The Yammouneh RPI record shows several well expressed lows that have been correlated to known and dated excursions in the global stack. For the upper part, Laschamps, Blake and Iceland basin excursions have been identified and labelled a, b, c according to Thouveny et al., 2008. We decided to not consider the interval between 30 and $45 \mathrm{~m}$ since the data were not continuous due to some sediment disturbances. From $45 \mathrm{~m}$ to the bottom, the Yammouneh record was correlated to several paleomagnetic excursions: CR0/Fram St (f), Portuguese Margin (g), CR1 (h) and
Levantine (i) (Thouveny et al., 2008). The obtained age model is in agreement with our previous age estimation (Develle et al., 2011) In addition, levels dated from interglacial peaks (MIS 1 and MIS 5.5) by both radiometric ages and paleomagnetism are composed of almost pure authigenic calcite and dominated by arboreal pollen taxa (Fig. 2aeb). By analogy, other intervals sharing the same characteristics suggest that all of them correspond to interglacials. allowing ages to be proposed for their depth limits based on MIS boundaries (Lisiecki and Raymo, 2005). When plotted versus depth radiometric and geomagnetic ages and those proposed from major environmental changes provide rather coherent age-depth relationships (Fig. 2). Between anchor points, ages were linearly interpolated. Despite uncertainties due to potential changes in sedimentation rates between anchor points, the time range of the geomagnetic events, gaps in sediment recovery and possible sedimentation hiatuses, our age-model allows to characterize the successive glacial and interglacial periods over the past $390 \mathrm{ka}$.

\section{Results and discussion}

\subsection{Main characteristics of glacial vs interglacial periods}

Intervals dominated by both calcite sedimentation and arboreal vegetation can be assigned to interglacial peaks of Marine Isotope Stages (MIS) 1, 5, 7 and 9 (Figs. 2b and 3). Interglacial peaks are 
characterized by: i) high content authigenic carbonate (Fig. 3a). Authigenic carbonates occur as rhomboedric crystals and calcified biogenic remains (e.g gastropods, ostracods, charophytes gyrogonites and calcified stems, fish otoliths), while detrital calcite forms poorly organized aggregates similar to those observed in alluvial fans; ii) abundant rests of lacustrine organisms testifying for the occurrence of a permanent water-body at the core site (Fig. 3c); iii) wooded landscapes (high Arboreal pollen percentages, AP \%) varying from cool conifer forests, temperate deciduous forests, to typical Mediterranean vegetation of medium-low altitude requiring winter rain but supporting hot and dry summer (Fig. 3deg). These features imply intense activity of the karstic system with significant water availability in both the surface and groundwater drainage areas.

Conversely, intervening periods represented by coloured silty clays show: i) the expansion of steppic vegetation (Fig. 3e) when tree growth was inhibited either by dry, cold, or low atmospheric $\mathrm{pCO}_{2}$ conditions; ii) scarce aquatic plant remains; iii) high magnetic mineral concentration (Fig. 3b) derived from the basin slopes associated with windblown minerals from remote sources, such as quartz (Fig. 3b) or feldspar almost absent in the watershed. These results are confirmed by the first component (PC1) of the PCAMultiproxy (Fig. 4a and Figure S1) that is positively loaded by all components reflecting detrital inputs and colour intensity, and negatively steered by $\mathrm{Ca}$, and pale colour. In general, at Yammouneh, glacials periods are mainly characterized by steppe-like vegetation on the watershed favouring erosional activity and deposition of siliciclastic particles in the basin.

The $d_{c}$-record runs roughly parallel to the planktonic foraminifera $d^{18} \mathrm{O}$ profiles $\left(d_{G \text {.ruber }}\right)$ in the nearest EMS marine cores (Fig. 3h), indicating that the source effect (the sea water oxygen isotopic composition, $d_{s w}$ ) is the prime factor controlling inland carbonate isotopic composition, as at other Levantine sites (BarMatthews et al., 2003; Kolodny et al., 2005). Nevertheless, large deviations between continental and marine records occur by times and show the contribution of other factors to the dc signal. Due to the lack of regional long term temperature reconstruction it was not possible to correct the signal for temperature changes. The enhanced thermal altitudinal lapse rate during glacials was thus neglected.

Assuming that the difference between EMS Sea Surface Temperature (SST) and the Yammouneh water-body temperature remained constant (see Gasse et al., 2011), the source effect was extracted by calculating $D d_{\text {land-sea }} 1 / 4 d_{c}$

$d_{\text {G. ruber }}$ (Fig. 3i). Dd $d_{\text {land-sea }}$ higher than the mean suggests ${ }^{18} \mathrm{O}-$ depleted water inputs. The

highest $\mathrm{Dd}$-values match $\mathrm{Ca}$ and tree pollen peaks and are attributed to enhanced inland rainfall amount. These intervals fit interglacial maxima and interstadials, suggested to be periods of higher precipitation in western Israel from comparison between marine and Soreq Cave speleothem isotope records (Bar-Matthews et al., 2003; Kolodny et al., 2005) Synchronous $d_{c}$ and $D d_{\text {apd-sea }}$ increases are attribytted to evaporative O- O-enrichment of the take riods, close to the transition from glacials to interglacials considering stratigraphic uncertainties (11e9 ka; 122 e127 ka; $330 \mathrm{e} 338$ ka). High $d_{c}$ associated to low $D d_{\text {land-sea-values likely reflects low }}$ local water temperature and/or reduced water balance of the water body. It was showed that, in the upper half of the core, the overall $\mathrm{Dd}$ profile is only slightly modified by integrating the ground-water temperature effect on precipitation composition and additional lake water cooling increasing $d_{c}$ (Gasse et al., 2011).

Arboreal vs. steppic vegetation, pale calcitic vs. coloured detrital deposits and $\mathrm{Dd}_{\text {land-sea }}$ generally indicate higher water availability during interglacials than during glacials. Four glacial-interglacial cycles are imprinted at Yammouneh. They suggest environmental changes in the same directions as in southeastern (Fig. 4a,b) and eastern Europe: wet interglacials and drier glacial phases (Tzedakis et al., 2006; Litt et al., 2014; Stockhecke et al., 2014). The southward deflections of the westerly storm-tracks along the southern Mediterranean coast during glacials, in response to the expansion of ice sheets over Eurasia, were proposed as the cause for generally wet glacial conditions in southern Levant (Begin et al., 2004; Enzel et al., 2008). These latitudinal shifts can also explain similarities between southeastern Europe and northern Levant, both deprived of moisture when rain-tracks were pushed southward.

\subsection{Distinctive signatures of the successive glacial and interglacial periods vs global climate forcing}

At Yammouneh, distinctive signatures between the successive interglacials and glacial periods reflect different combinations of regional and global forcing. The EMS underwent large glacialinterglacial fluctuations in $\mathrm{d}_{\mathrm{sw}}$ linked to global ice volume and in SST, but also fingerprinted low latitude mechanisms (Fig. 4cee). When the African monsoon strength was enhanced, North African runoff (NAR) brought massive influxes of ${ }^{18} \mathrm{O}$-depleted freshwater of tropical origin to the EMS (Ziegler et al., 2010). This results in sharp $d_{s w}$ lowering and often in EMS sapropel events (S), which responded with a short time-lag to boreal summer insolation maxima (Fig. 4h). S-events are rapidly followed by SST rises (Fig. 4c) (Emeis et al., 2003) and higher rainfall amount as suggested by Yammouneh AP-values (Fig. 4a) and by Soreq Cave speleothem stable isotopes (Kolodny et al., 2005; Almogi-Labin et al., 2009).

During MIS 9, calcite sedimentation and arboreal oak pollen predominated in two phases (Fig. 3f). Insolation forcing was moderate compared to MIS 7 and 5 (Fig. 4h), but Greenhouse Gas Concentrations (GHG) reached their highest levels around $330 \mathrm{ka}$ (Petit et al., 1999; Loulergue et al., 2008); $\mathrm{CO}_{2}$-level remained high until ca. 300 ka (Fig. 4f). We suggest that the GHG-associated warming favoured inland terrestrial and aquatic bioactivity, calcite precipitation, and water-body evaporation thus high $d_{c}$, and high $\mathrm{Dd}_{\text {land-sea }}$ during S10 (Fig. 3h,i). Conversely, MIS 7 experienced large insolation changes due to maximum eccentricity and the largest amplitude of obliquity and precession variations. EMS-SST and GHG are high at the MIS 7 onset, but rapidly dropped to glacial-like values; ice sheets developed over Eurasia and persisted until ca. 215 ka (Ehlers and Gibbard, 2004). Vegetation records from SE and SW Europe show a similar trend characterised by a forest collapse indicating pronounced cooling and aridification on land (Roucoux et al., 2006; Tzedakis et al., 2006; Litt et al., 2014). In the Yammouneh area, the highest frequencies of aquatic plant and of high altitude conifer pollen (Fig. 3c,e) during early-mid MIS 7 indicate wet and cool conditions reducing evaporation rate. The indirect tropical influence induced, however, EMS sapropel events (S8) leading to $d_{\mathrm{sw}}$ decreases in the EMS and high $\mathrm{Dd}_{\text {land-sea }}$ at Yammouneh, although the temporal resolution for the record is not well constrained for this specific time interval. Late MIS 7 was milder. MIS 5 shows three wet intervals of decreasing amplitude (MISs 5e, 5c, 5a) coincident with S5eS3, although calcite sedimentation was subdued during MIS 5.3 due to dilution of authigenic carbonates by detrital inputs. The vegetation signal at Yammouneh during MIS 5 interstadials is close to southern Europe pollen records (e.g. Tenaghi Philippon, Fig. 4b). The remarkable $d_{c}$ and $\mathrm{Dd}_{\text {land-sea }}$ increases at $128 \mathrm{e} 122 \mathrm{ka}$ (the warm Last Interglacial maximum), in phase with a peak of evergreen oak pollen (Fig. 3gei), is attributed to increased seasonal thermal forcing, possibly linked to a high North Atlantic Oscillation index (Felis et al., 2004). Between the wet MIS 5 intervals, the forest deterioration led to steppic landscapes favouring mechanical erosion and 
accumulation of detrital particles. Early MIS 1 underwent mild humid conditions when seasonal insolation contrasts were relatively weak.

For glacial stages, MIS 8 evolved by steps toward dry, cool conditions but remained wet and warm enough for oak growth until ca. $260 \mathrm{ka}$ (Fig. 3g). Slightly warmer conditions during MIS 8 as compared to MIS 6 might explain relatively higher representation of evergreen oak. MIS 8 glacial conditions were moderate, as shown by regional records (Fig. $4 \mathrm{aec}$ ) and by the global stack of benthic foraminifera $\mathrm{d}^{18} \mathrm{O}$ (Fig. 4f) (Lisiecki and Raymo, 2005). This picture differs with SW Europe vegetation records showing extreme glacial conditions probably influenced by North Atlantic Heinrich-type event at the beginning of MIS 8 (Roucoux et al., 2006). During MIS 6, EMS-SST was low, GHG values dropped sharply until $140 \mathrm{ka}$ and a huge ice sheet grew far onto the Eurasian continent (Ehlers and Gibbard, 2004). At Yammouneh, this glacial stage started by a dry, cold episode, but was followed by more humid conditions Rainfall increases are suggested by several proxies around $175 e 170$ ka (S6) and after $150 \mathrm{ka}$. Wetter events roughly in phase with NAR peaks were also recorded in western Mediterranean (Bard et al., 2002), in Greece (Tzedakis et al., 2006; Roucoux et al., 2011) (Fig. 4b), and in the eastern Mediterranean at Soreq Cave where speleothem isotope data show that cold but relatively humid conditions persisted during all MIS 6 (Ayalon et al., 2002). High resolution studies from eastern Anatolia indicate millennial climate variability intercalated by warm/wet conditions for the early period of MIS 6 (Stockhecke et al., 2014). However, the transition from MIS 6 to MIS 5 at Yammouneh, seems to be more progressive than in other eastern Mediterranean records, especially the paleovegetation signal, which never reached glacial levels like at the beginning of MIS 6. From MIS 4 to MIS 2, the drying trend initiated after MIS 5.5 accentuated, although punctuated by short wetter pulses. Local drought culminated during MIS 2, when the Yammouneh basin was almost devoid of vegetation, leaving bare soils prone to freeze-thaw processes and mechanical erosion. MIS 2 cooling at Yammouneh was probably larger than the $10 \mathrm{e} 12{ }^{1} \mathrm{C}$ SST departure due to enhanced thermal altitudinal lapse rate during glacials (Kuhlemann et al., 2008). Water storage as ice in the western highlands has likely contributed to the local deficit in liquid water: moraine boulders on the western flank of Mount Lebanon were ${ }^{36} \mathrm{Cl}$-dated from the Last Glacial period and deglaciation (Moulin et al., 2011). At that time, speleothems in Mount Hermon only grew during short warmer intervals fitting Greenland interstadial stages due to freezing conditions during the coldest stages (Ayalon et al., 2013).

\section{Conclusions}

The Yammouneh sedimentary sequence provides a unique hydroclimatic sub-continuous record of the last $400 \mathrm{ka}$ in the northern Levant and fills a gap in data coverage between southern Levant and southeastern Europe. The multi-proxy study of the paleolake deposits allows characterising local vegetation, erosional processes, in situ productivity and qualitative hydrology of the Yammouneh basin in order to assess the observed environmental changes.

All climate-related variable at Yammouneh varied at glacial/ interglacial scale over the last four climate cycles. During interglacials, high local and regional moisture is evidenced by dense arboreal vegetation of varied types, lacustrine organism rests, and authigenic carbonate production. During glacials, variable aridity conditions are inferred from open steppic landscapes favouring physical erosion, and local terrigenous inputs. In particular, MIS 8 and MIS 6 were relatively humid contrasting with the dry conditions of MIS 2.
At glacial/interglacial scale, the Yammouneh record is in line with warm/wet interglacial and cold/dry glacial periods as recorded from long term climate records from SW/SE Europe and near East. The northern Levant therefore responded to long-term orbitally-induced temperature fluctuations, ice sheet waxing/waning in the Northern hemisphere and climatic changes in the North Atlantic. At regional scale, a southern shift of the atmospheric belts due to the presence of ice sheets may partly explain hydrological evolution in the Levant; the North-South climatic heterogeneity occurring today was reversed during glacial phases.

Differences in the successive glacial-interglacial cycles are explained by various climate forcing factors. We suggest that precessionaly-induced factors, in addition to GHG-associated warming, could have probably imprinted the Yammouneh record during sapropel events (S10, S8, S5, S4, S3), and in the first part of MIS 6 (S6) and MIS 8. As an additional local factor, water was possibly stored as ice on Mount Lebanon and in frozen soils during the coldest glacial periods. The dc signal is complex but is reconciled with other proxies when corrected for the "temperature effect" and the "source effect", and when considering interglacial enhanced seasonality.

Further work is needed to refine the chronology accuracy. On the other hand, other reconstructions from northern Levant are needed for capturing fine scale temporal and spatial variability of hydroclimate conditions. Last-generation regional downscaling climatic models (grid spacing $20 \mathrm{~km}$ ) and hydrogeological modelling of the Mount Lebanon-Yammouneh system would certainly bring important insights on the mechanisms driving environmental changes in this area of steep orography. Once coupled with archaeological data, the Yammouneh record will provide a step in understanding human migrations and site occupation in the Levant, in response to regional changes in climaterelated water resources.

\section{Competing financial interests}

The authors declare no competing financial interests.

\section{Acknowledgements}

We thank P. Tapponnier and A. Sursock who encourage FG to undertake paleoenvironmental studies in the Yammouneh basin. M. Decobert and his team for coring. The French-Lebanese CEDRE project, and the French CNRS INSU-ECLIPSE and LEFE-EVE (PALEOLIBAN) programmes provided financial support to CEREGE (FG and LV). Part of the Rock and Paleomagnetic measurements were funded through the MAGORB project (ANR-09-BLAN-0053-01). ALD was granted by the French Ministery of Research during the 3 years of her PhD thesis. We thank S. Le Burel and N. Buchet for technical assistance.

\section{References}

Almogi-Labin, A Bar-Matthews, M. Shriki, D., Kolosovsky, E, Paterne, M Schilman, B., Ayalon, A., Aizenshtat, Z., Matthews, A., 2009. Climatic variability during the last $90 \mathrm{ka}$ on the southern and northern Levantine basin as evident from marine records and speleothems. Quat. Sci. Rev. 28, 2882e2896.

Alpert, P., Ziv, B., 1989. The Sharav cyclone: observations and some theoretical considerations. J. Geophys. Res. 94, 18495e18514.

Ayalon, A., Bar-Matthews, M., Kaufman, A., 2002. Climatic conditions during marine oxygen isotope 6 in the eastern Mediterranean region from the isotopic composition of speleeothems of Soreq Cave, Israel. Geology 30, $303 e 306$. 
Ayalon, A., Bar-Matthews, M., Frumkin, A., Matthews, A., 2013. Last Glacial warm events on Mount Hermon : the southern extension of the Alpine karst range in the east Mediterranean. Quat. Sci. Rev. 59, 43 e56.

Bard, E., Delaygue, G., Rostek, F., Antonioli, F., Silenzi, S., Schrag, D.P., 2002. Hydrological conditions over the western Mediterranean basin during the deposition of the cold Sapropel 6 xca. 175 kyr BP. Earth Planet. Sci. Lett. 202 481 e494.

Bar-Matthews, M., Ayalon, A., Gilmour, M., Matthews, A., Hawkesworth, C.J., 2003. Sea-land oxygen isotopic relationship from planktonic foraminifera and speleothems in the Eastern Mediterranean region and their implication for paleorainfall during interglacial intervals. Geochim. Cosmochim. Acta 67 (17) 3181 e3199.

Begin, Z.B., Stein, M., Katz, A., Machlus, M., Rosenfeld, A., Buchbinder, B., Bartov, Y. 2004. Southward migration of rain tracks during the Last Glacial, revealed by salinity gradient in Lake Lisan (Dead Sea rift). Quat. Sci. Rev. 23, 1627e1636.

Berger, A., Loutre, M.F., 1991. Insolation values for the climate of the last 10 million years. Quat. Sci. Rev. 10, 297e317.

Channell, J.E.T., Xuan, C., Hodell, D.A., 2009. Stacking paleointensity and oxygen isotope data for the last 1.5 Myr (PISO-1500). Earth Planet. Sci. Lett. 283, 14e23.

Develle, A.L., Gasse, F., Vidal, L., Williamson, D., Demory, F., Van Campo, E., Ghaleb, B., Thouveny, N., 2011. A 250 ka sedimentay record from a small karstic lake in the northern Levant (Yammoûneh, Lebanon). Paleogeogr. Paleoclimatol. Paleoecol. 305, 10e27.

Develle, A.L., Herreros, J., Vidal, L., Sursock, A., Gasse, F., 2010. Controlling factors on a paleo-lake oxygen isotope record (Yammoûneh, Lebanon) since the Last Glacial Maximum. Quat. Sci. Rev. 29 (7e8), 865e886.

Ehlers, J., Gibbard, P.L., 2004. Quaternary Glaciations. Extent and Chronology. Part 1: Europe. Elsevier, Amsterdam.

Emeis, K.C., Schulz, H., Struck, U., Rossignol-Strick, M., Erlenkeuser, H., Howell, M.W., Kroon, D., Mackensen, A., Ishizuka, S., Oba, T., Sakamoto, T., Koizumi, I., 2003. Eastern Mediterranean surface water temperatures and $\mathrm{d}^{18} \mathrm{O}$ during deposition of sapropels in the late Quaternary. Paleoceanography 18, 1005. http:// dx.doi.org/10.1029/2000PA000617.

Enzel, Y., Amit, R., Dayan, U., Crouvi, O., Kahana, R., Ziv, B., Sharon, D., 2008. The climatic and physiographic controls of the eastern Mediterranean over the late Pleistocene climates in the southern Levant and its neighboring deserts. Glob. Planet. Change 60, 165e192.

Faegri, K., Iversen, I., 1989. Textbook of Pollen Analysis, fourth ed. Wiley, London.

Felis, T., Lohmann, G., Kuhnert, H., Lorenz, S.J., Scholz, D., P๕tzold, J., Al-Rousan, S.A., Al-Moghrabi, S.M., 2004. Increased seasonality in Middle East temperatures during the Last Interglacial period. Nature 429, 164e168.

Frumkin, A., Bar-Yosef, O., Schwarz, H.P., 2011. Possible paleohydrologic and paleoclimatic effects on hominin migration and occupation of the Levantine Middle Paleolithic. J. Hum. Evol. 60, 437e451.

Gasse, F., Vidal, L., Develle, A.-L., Van Campo, E., 2011. Hydrological variability in the Northern Levant: a 250 ka multiproxy record from the Yammoûneh (Lebanon) sedimentary sequence. Clim. Past. 7, 1261 e1284.

Giorgi, F., Lionello, P., 2008. Climate change projections in the Mediterranean region. Glob. Planet. Change 63, 90e104.

Jacobeit, J., Wanner, H., Luterbacher, J., Beck, C., Philipp, A., Sturm, K., 2003. Atmospheric circulation variability in the North-Atlantic-European area since the mid-seventeenth century. Clim. Dyn. 20, 341e352.

Kolodny, Y., Stein, M., Machlus, M., 2005. Sea-rain-lake relation in the Last Glacial East Mediterranean revealed by $d^{18} \mathrm{Oed}^{13} \mathrm{C}$ in Lake Lisan aragonites. Geochim. Cosmochim. Acta 69, 4045e4060.

Kuhlemann, J., Rohling, E.J., Krumrei, I., Kubik, P., Ivy-Ochs, S., Kucera, M., 2008. Regional synthesis of Mediterranean atmospheric circulation during the Last Glacial Maximum. Science 231, 1338e1340.

Lisiecki, E., Raymo, M.E., 2005. A Plio-Pleistocene stack of 57 globally distributed benthic $\mathrm{d}^{18} \mathrm{O}$ record. Paleoceanography 20, PA1003. http://dx.doi.org/10.29/ 2004PA001071.
Lisker, S., Vaks, A., Bar-Matthews, M., 2010. Late Pleistocene palaeoclimatic and palaeoenvironmental reconstruction of the Dead Sea area (Israel), based on speleothems and cave stromatolites. Quat. Sci. Rev. 29, 1201 e1211.

Litt, T., Pickarski, N., Heumann, G., Stockhecke, M., Tzedakis, P.C., 2014. A 600,000 year long continental pollen record from Lake Van, eastern Anatoloia (Turkey) Quat. Sci. Rev. 104, 30e41. http://dx.doi.org/10.1016/j.quaascirev.2014.03.017.

Loulergue, L., Schilt, A., Spahni, R., Masson-Delmotte, V., Blunier, T., Lemieux, B. Barnola, J.-M., Raynaud, D., Stocker, T.F., Chappellaz, J., 2008. Orbital and millennial-scale features of atmospheric $\mathrm{CH} 4$ over the past 800,000 years. Nature 453, 383e386.

Milano, M., Ruelland, D., Fernandez, S., Dezetter, A., Fabre, J., Servat, E., 2012. Facing climatic and anthropogenic changes in the Mediterranean basin: what will be the medium-term impact on water stress ? C.R. Geosci. 344, 432 e 440.

Moulin, A., Benedetti, L., Van der Woerd, J., Elias, A., Blard, P.H., Finkel, R., Braucher, R., Lave, J., Bourles, D., Daeron, M., the Paul, Tapponnier Team, 2011. LGM glaciers on Mount Lebanon? New insights from ${ }^{36} \mathrm{Cl}$ exposure dating of moraine boulders. Geoph. Res. Abstr. 13. EGU2011e11465.

Paillard, D., Labeyrie, L., Yiou, P., 1996. Macintosh program peforms time-series analysis. EOS. Trans. AGU 77.

Petit, J.R., Jouzel, J., Raynaud, D., Barkov, N.I., Barnola, J.-M., Basile, I., Bender, M.I. Chappellaz, J., Davisk, J.M., Delaygue, G., Delmotte, M., Kotlyakov, V.M. Legrand, M., Lipenkov, V.Y., Lorius, C., Pepin, L., Ritz, C., Saltzmank, E. Stievenard, M., 1999. Climate and atmospheric history of the last 420,000 years from the Vostok ice core, Antarctica. Nature 399, 429e436.

Roucoux, K.H., Tzedakis, P.C., Lawson, I.T., Margari, V., 2011. Vegetation history of the penultimate glacial period (Marine Isotope Stage 6) at Ioannina, north-wes Greece. J. Quat. Sci. 26, 616e626.

Robinson, S., Black, S., Sellwood, B.W., Valdes, P.J., 2006. A review of paleoclimates and paleoenvironments in the Levant and Eastern Mediterranean from 25,000 to 5,000 years BP: setting the environmental background for the evolution of human civilisation. Quat. Sci. Rev. 25, 1517e1541.

Roucoux, K.H., Tzedakis, P.C., de Abreu, L., Shackleton, N.J., 2006. Climate and vegetation changes 180,000 to 345,000 years ago recorded in a deep-sea core of Portugal. Earth Planet. Sci. Lett. 249, 307e325.

Stockhecke, M., Sturm, M., Brunner, I., Schmincke, H.-U., Sumita, M., Kipfer, R Cukur, D., Kwiecien, O., Anselmetti, F., 2014. Sedimentary evolution and environmental history of Lake Van (Turkey) over the past 600,000 years. Sedimentology 61, 1830e1861. http://dx.doi.org/10.1111/sed.12118.

Thouveny, N., Bourles, D.L., Saracco, G., Carcaillet, J.T., Bassinot, F., 2008. Paleoclimatic context of geomagnetic dipole lows and excursions in the Bruhnes, clue for an orbital influence on the dynamo? Earth Planet. Sci. Lett. 275, $269 e 284$.

Tzedakis, P.C., Hooghiemstra, H., Palike, H., 2006. The last 1.35 million years at Tenaghi Philippon: revised chronostratigraphy and long-term vegetation trends. Quat. Sci. Rev. 25, 3416e3430.

Verheyden, S., Nader, F.G., Cheng, H.J., Edwards, L.R., Swennen, R., 2008. Paleoclimate reconstruction in the Levant region from the geochemistry of a Holocene stalagmite from the Jeita cave. Leban. Quat. Res. 70, 368e381.

Waldmann, N., Torfstein, A., Stein, M., 2010. Northward intrusions of low- and midlatitude storms across the Saharo-Arabian belt during past interglacials. Geology 38,567 e 570

Wang, P., Tian, J., Lourens, L., 2010. Obscuring of long eccentricity cyclicity in Pleistocene oceanic carbon isotope records. Earth Planet. Sci. Lett. 290, 319e330.

Ziegler, M., Tuenter, E., Lourens, L.J., 2010. The precession phase of the boreal summer monsoon as viewed from the eastern Mediterranean (ODP site 968). Quat. Sci. Rev. 29, 1481e1490.

Ziv, B., 2001. A subtropical rainstorm associated with a tropical plume over Africa and the Middle East. Theor. Appl. Climatol. 69, 91e102.

Ziv, B., Saaroni, H., Romem, M., Heifetz, E., Harnik, N., Baharad, A., 2010. Analysis of conveyor belts in winter Mediterranean cyclones. Theor. Appl. Climatol. 99, $441 \mathrm{e} 455$. 